\title{
MEDICINAL USES, BIOLOGICAL AND CHEMICAL PROPERTIES OF WILD GRAPE (LANNEA EDULIS): AN INDIGENOUS FRUIT PLANT OF TROPICAL AFRICA
}

\author{
ALFRED MAROYI* \\ Department of Botany, Medicinal Plants and Economic Development Research Centre, University of Fort Hare, \\ Private Bag X1314, Alice 5700, South Africa. E-mail: amaroyi@ufh.ac.za
}

Received: 14 June 2019; Revised and Accepted: 13 July 2019

\begin{abstract}
Lannea edulis is a fruit plant widely used as herbal medicine throughout its distributional range in tropical Africa. This study was aimed at providing a critical review of the biological activities, phytochemistry, and medicinal uses of L. edulis. Documented information on the botany, biological activities, medicinal uses, and phytochemistry of L. edulis was collected from several online sources which included BMC, Scopus, SciFinder, Google Scholar, Science Direct, Elsevier, PubMed, and Web of Science. Additional information on the botany, biological activities, phytochemistry, and medicinal uses of L. edulis was gathered from pre-electronic sources such as book chapters, books, journal articles, and scientific publications sourced from the University library. This study showed that the bark, leaves, rootbark, and roots of L. edulis are used as antiabortifacient and herbal medicine to dilate birth canal, dizziness, sore eyes, sexually transmitted diseases, amenorrhea and dysmenorrhea, malaria, bilharzia, and gastrointestinal problems. Ethnopharmacological research revealed that L. edulis extracts and compounds have anthelmintic, anti-human immunodeficiency virus, antihyperglycemic, antihyperlipidemic, antimalarial, antimicrobial, antioxidant, and cytotoxicity activities. Future studies should focus on conducting detailed phytochemical, pharmacological, and toxicological evaluations of L. edulis crude extracts as well as compounds isolated from the species.
\end{abstract}

Keywords: Anacardiaceae, Ethnopharmacology, Herbal medicine, Indigenous pharmacopeia, Lannea edulis.

(C) 2019 The Authors. Published by Innovare Academic Sciences Pvt Ltd. This is an open access article under the CC BY license (http://creativecommons. org/licenses/by/4. 0/) DOI: http://dx.doi.org/10.22159/ajpcr.2019.v12i9.34580

\section{INTRODUCTION}

Several plant species with edible fruits, leaves, or seeds in tropical Africa are also valued as herbal medicines [1-6]. In recent years, there has been a resurgence of interest in wild edible fruits and vegetables as their consumption has been associated with lowered risk of stroke, heart diseases, cancer, aging, diabetes, and hypertension. Research by Marco et al. [7], Vinson et al. [8], and Wolfe and Liu [9] showed that phytochemicals associated with edible plants are responsible for the protection of human health against chronic degenerative diseases. Synthetic and natural antioxidants have been targeted as potential agents for preventing and treating chronic degenerative diseases [10-13]. Previous research showed that edible fruits, spices, microalgae, vegetables, and medicinal plants could be important sources of natural antioxidants required for preventing and treating oxidative stress-related diseases [13-20]. In tropical Africa, wild grape, Lannea edulis (Sond.) Engl. is one of the indigenous fruit plants [21-34] that are widely used as herbal medicines. According to FAO [25], the fruits can be dried for later use, and the dried fruits are made into a fermented drink. In Zimbabwe, the underground rhizomes of L. edulis are consumed, particularly by children [29], and in South Africa, the rhizome is edible after cooking. Research by Van Wyk [35] showed that the fruits of L. edulis have commercial potential in the development of new food and beverage products which include jam, jelly, dried fruits, and other processed products that can be used as food additives. Research by Van Wyk et al. [36] and Van Wyk and Gericke [28] showed that $L$. edulis is among the species widely used as herbal medicines in South Africa. Research by Cunningham [37] showed that roots of $L$. edulis are sold as herbal medicines in Malawi. It is against this background that this study was undertaken aimed at appraising the medicinal uses and phytochemistry and biological activities of L. edulis.

\section{TAXONOMY AND DESCRIPTION OF L. EDULIS}

L. edulis is a member of the Anacardiaceae family, which includes economically important genera such as cashew (Anacardium L.), mango (Mangifera L.), marula (Sclerocarya Hochst.), and sumac (Rhus L.) [38].
The name of the genus, "Lannea," is derived from a Latin word "lana" which translates to "wool" in reference to young plant parts which are densely hairy or possibly to the wool on the roots of some Lannea species [21,27]. The specific name "edulis" is a Latin word meaning "edible", in reference to edible fruits of the species [27]. Two varieties of L. edulis are recognized, that is L. edulis var. edulis and L. edulis var. glabrescens (Engl.) Burtt Davy. Synonyms associated with L. edulis include L. nana Engl. and Odina edulis Sond. [39-41]. Other Lanneas species which include L. acida A. Rich., L. discolor (Sond.) Engl., L. microcarpa Engl. and K. Krause, L. schimperi (Hochst. ex A. Rich.) Engl., and L. schweinfurthii (Engl.) Engl. are widely used as herbal medicines in tropical Africa [42-46].

L. edulis is a small deciduous, perennial shrublet of up to a meter in height, with short, leafy branches developing from a woody, underground rootstock. L. edulis has a robust underground, branching stem, which may be up to $12.5 \mathrm{~cm}$ thick and anchored by a deep root system [25]. The stem is purple-brown in color, and the leaves are compound, densely covered with silvery hairs when young. The flowers are small, yellowish, tinged with red and occur in erect spikes near the ground. The fruits are red, fleshy drupe when ripe and together with flowers normally appear before the leaves and are conspicuous on burnt ground. L. edulis has been recorded in Angola, Botswana, Burundi, the Democratic Republic of Congo (DRC), Ethiopia, Ivory Coast, Kenya, KwaZulu-Natal, Malawi, Mozambique, Namibia, Northern Provinces, Rwanda, Swaziland, Tanzania, Uganda, Zambia, and Zimbabwe [32,39-41,47-51]. The species has been recorded in grassland, vleis, open woodland, on rocks, swamps, and termite mounds at an altitude ranging from $305 \mathrm{~m}$ to $1740 \mathrm{~m}$ above sea level [32,39-41,47-50].

\section{MEDICINAL USES OF L. EDULIS}

The bark, leaves, rootbark, and roots of L. edulis are used as herbal medicines against 39 human diseases in tropical Africa (Table 1). L. edulis is mainly used as an antiabortifacient, herbal medicine to dilate birth canal, dizziness, sore eyes, sexually transmitted diseases, amenorrhea and dysmenorrhea, malaria, bilharzia, and gastrointestinal problems (Fig. 1). In South Africa and Malawi, the roots of L. edulis 
Table 1: Medicinal uses of Lannea edulis

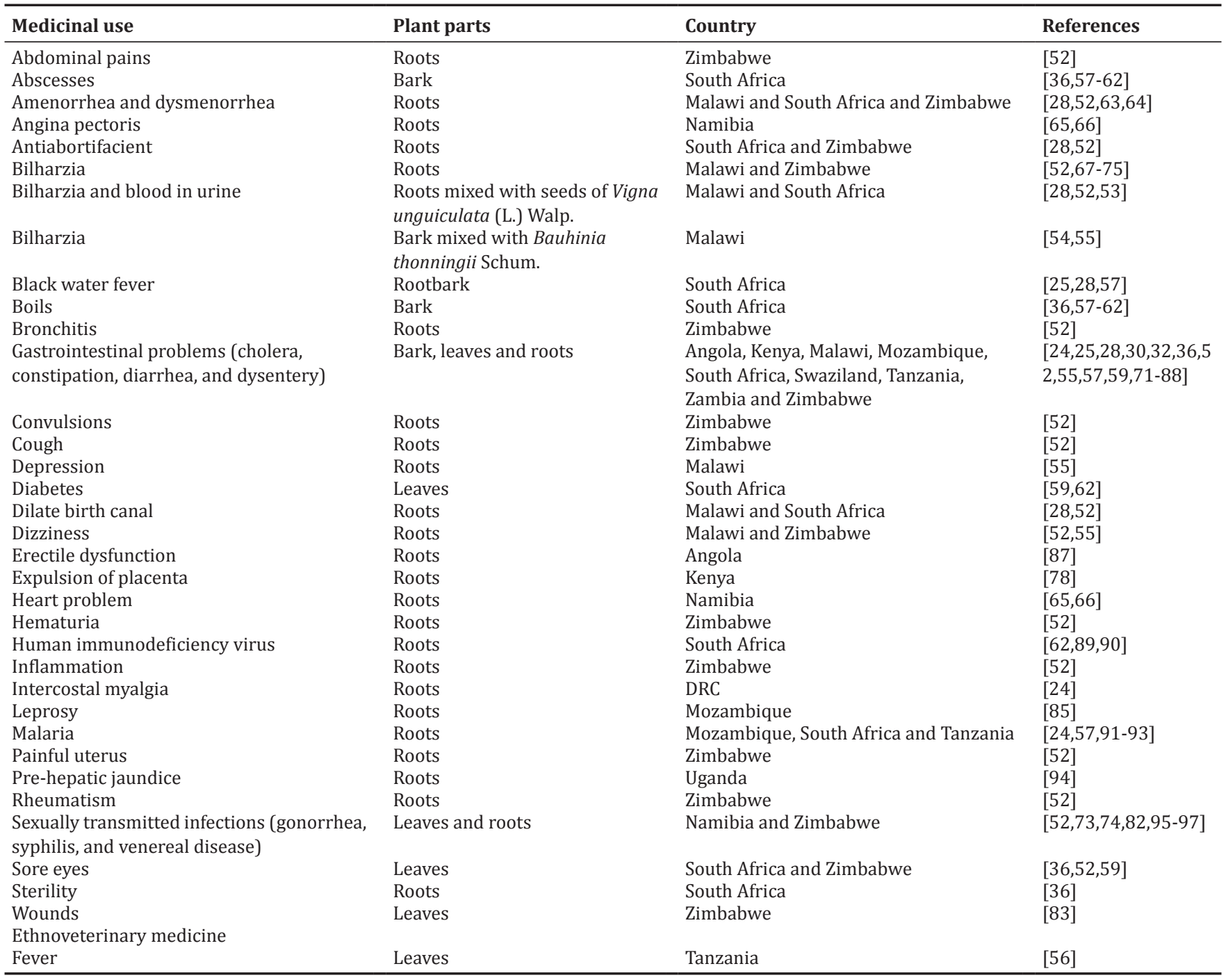

are mixed with seeds of Vigna unguiculata (L.) Walp. as remedies for bilharzia and blood in urine $[28,52,53]$. In Malawi, the bark of L. edulis is mixed with the bark of Bauhinia thonningii Schum. as herbal medicine for bilharzia $[54,55]$. The leaves of $L$. edulis are also used as ethnoveterinary medicine in Tanzania [56].

\section{PHYTOCHEMISTRY OF L. EDULIS}

Amusan et al. [80], Banda [86], and Banda et al. [98] identified alkaloids, cardiac glycosides, flavonoids, polyphenols, saponins, steroids, and tannins from the bark, leaves, and roots of L. edulis. Munodawafa [83] found the total phenolic content of leaf extracts of L. edulis to be $0.3 \mathrm{mg}$ of tannic acid equivalent per $100 \mathrm{mg}$. Queiroz et al. [99] identified two alkylphenols, 3-[14'-nonadecenyl]phenol and 3-[16'-heptadecenyl] phenol and three dihydroalkylhexenones, 5-[14-heptadecenyl]-4,5dihydroxy-2-cyclohexenone, 5-[16'-nonadecenyl]-4S,5S-dihydroxy-2cyclohexenone, and 5-[16-nonadecenyl]-4,5-dihydroxy-2-cyclohexenone from the rootbark of L. edulis (Fig. 2)

\section{BIOLOGICAL ACTIVITIES OF L. EDULIS}

Biological activities of $L$. edulis extracts and compounds isolated from the species include anthelmintic [100], antihuman immunodeficiency virus (HIV) [89], antihyperglycemic [86,98], antihyperlipidemic $[86,98]$, antimalarial [91], antimicrobial [83,101,102], antioxidant [86,99], and cytotoxicity $[89,103]$ activities.

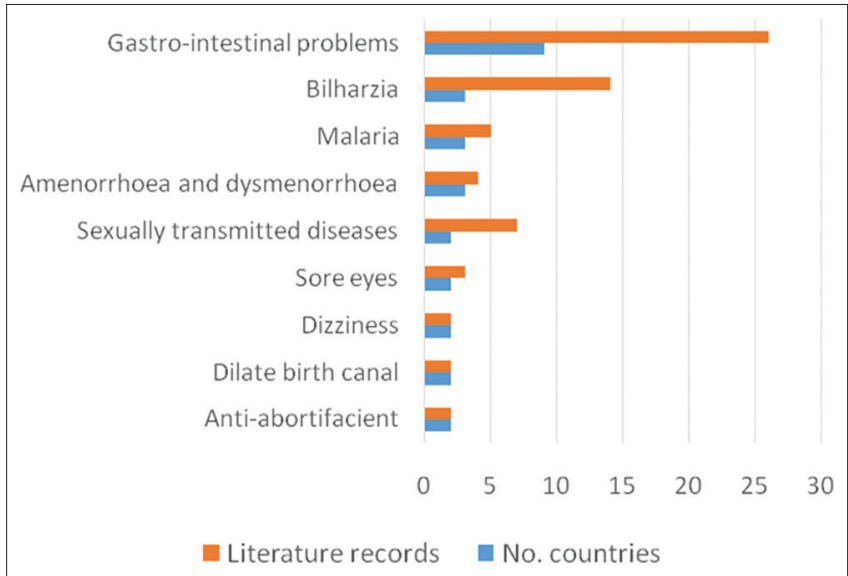

Fig. 1: Medicinal uses of Lannea edulis derived from literature records

Anthelmintic activities

Mølgaard et al. [100] evaluated the anthelmintic activities of L. edulis leaf and stem extracts against schistosomules of the trematode Schistosoma mansoni and cysticercoids of the cestode of Hymenolepis 

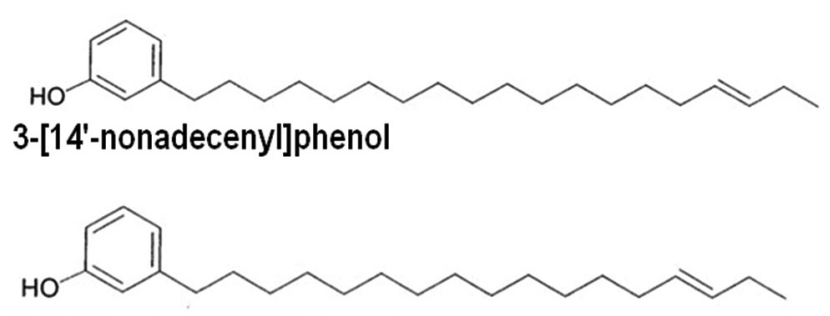

3-[16'-heptadecenyl]phenol

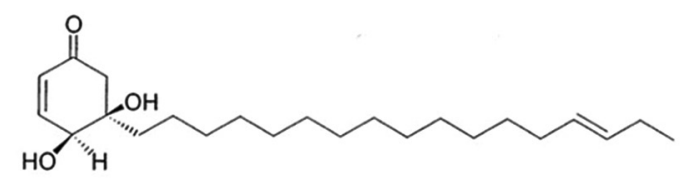

5-[14-heptadecenyl]-4,5-dihydroxy-2-cyclohexenone

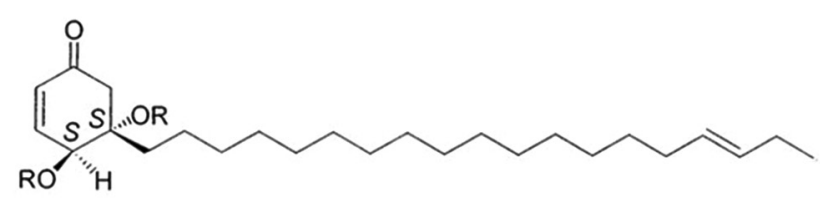

5-[16'-nonadecenyl]-4S,5S-dihydroxy-2-cyclohexenone

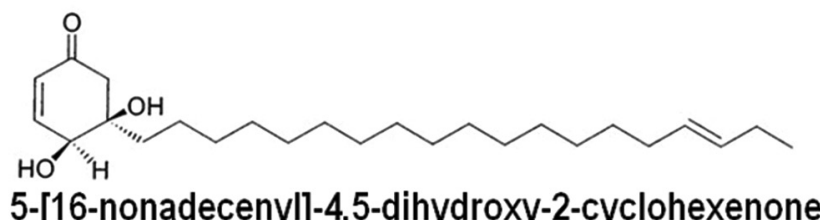

5-[16-nonadecenyl]-4,5-dihydroxy-2-cyclohexenone

Fig. 2: Alkylphenols and dihydroxyalkyl hexanones that have been identified from the rootbark of $L$. edulis

diminuta with praziquantel as a positive control. The extracts killed the newly excysted cysticercoids within an hour, when incubated in a culture medium. The lethal concentrations $\left(\mathrm{LC}_{50}\right)$ of $L$. edulis were $4.0 \mathrm{mg} / \mathrm{ml}$ and $3.0 \mathrm{mg} / \mathrm{ml}$ after $1 \mathrm{~h}$ and $24 \mathrm{~h}$, respectively [100].

\section{Anti-HIV activities}

Sigidi et al. [89] evaluated the anti-HIV activities of aqueous root extract of $L$. edulis using the reverse transcriptase assay. The extract at a concentration of $50 \mu \mathrm{g} / \mathrm{ml}$ and $100 \mu \mathrm{g} / \mathrm{ml}$ showed inhibition of $20 \%$ and $30 \%$, respectively [89].

\section{Antihyperglycemic activities}

Banda [86] and Banda et al. [98] evaluated the antihyperglycemic activities of the aqueous leaf extracts of $L$. edulis in alloxan-induced diabetic male albino rats. The extract exhibited dose-dependent antihyperglycemic effects $[86,98]$.

\section{Antihyperlipidemic activities}

Banda [86] and Banda et al. [98] evaluated the antihyperlipidemic activities of the aqueous leaf extracts of $L$. edulis in alloxan-induced diabetic male albino rats. The extract exhibited dose-dependent antihyperlipidemic effects [86,98].

\section{Antimalarial activities}

Gessler et al. [91] evaluated the antimalarial activities of crude ethanol, petroleum ether, ethyl acetate, and water root extracts of $L$. edulis using the $\left({ }^{3} \mathrm{H}\right)$ hypoxanthine incorporation assay against multidrug-resistant Plasmodium falciparum strain K1 and the chloroquine-sensitive strain NF54. The ethyl acetate, petroleum ether, and ethanol extracts exhibited activities against $P$. falciparum strain $\mathrm{K} 1$ with half maximal inhibitory concentration (IC ${ }_{50}$ ) values of $17.0 \mu \mathrm{g} / \mathrm{ml}, 18.0 \mu \mathrm{g} / \mathrm{ml}$, and $40.0 \mu \mathrm{g} / \mathrm{ml}$, respectively, while water extracts were inactive [91].

\section{Antimicrobial activities}

Munodawafa [83] and Munodawafa et al. [101] evaluated the antimicrobial activities of leaf methanol extracts of $L$. edulis against Aspergillus niger, Candida albicans, Escherichia coli, Pseudomonas aeruginosa, Staphylococcus aureus, and Staphylococcus Group A using the agar well-diffusion method with $10 \mu \mathrm{g}$ each of ampicillin, amoxicillin, gentamicin, tetramycin, and amphotericin $B$ as positive controls. The extracts showed activities against $A$. niger, $C$. albicans, P. aeruginosa, S. aureus, and Staphylococcus Group A with zone of inhibition ranging from $1.0 \mathrm{~mm}$ to $5.0 \mathrm{~mm}$ against $4.0 \mathrm{~mm}$ to $13.0 \mathrm{~mm}$ exhibited by the positive controls. The minimum inhibitory concentration (MIC) values against A. niger, C. albicans, P. aeruginosa, S. aureus, and Staphylococcus Group A ranged from $2.5 \mathrm{mg} / \mathrm{ml}$ to $5.0 \mathrm{mg} / \mathrm{ml}$ [83,101]. Munodawafa [83] found the minimum bactericidal or fungicidal concentration of the extracts against A. niger, C. albicans, P. aeruginosa, S. aureus, and Staphylococcus Group A to range from $10.0 \mathrm{mg} / \mathrm{ml}$ to $>10.0 \mathrm{mg} / \mathrm{ml}$. Chivengwa et al. [102] evaluated the antimicrobial activities of the leaf ethanol and aqueous extracts of $L$. edulis against E. coli and Salmonella spp. using the microdilution method. The extracts exhibited activities against tested pathogens with MIC value of $10 \mu \mathrm{m} / \mathrm{mL}$ [102].

\section{Antioxidant activities}

Queiroz et al. [99] evaluated the antioxidant activities of methanol and dichloromethane rootbark extracts of $L$. edulis using the $0.2 \%$ diphenylpicrylhydrazyl (DPPH) free radical scavenging assay. The dichloromethane extract exhibited activities. Similarly, Queiroz et al. evaluated the antioxidant activities of the compounds 3-[14'-nonadecenyl] phenol, 3-[16'-heptadecenyl]phenol, 5-[14-heptadecenyl]-4,5-dihydroxy2-cyclohexenone, 5-[16'-nonadecenyl]-4S,5S-dihydroxy-2-cyclohexenone, and 5-[16-nonadecenyl]-4,5-dihydroxy-2-cyclohexenone isolated from the rootbark of $L$. edulis using the DPPH free radical scavenging assay with Quercetin and [2,6-di-(tert-butyl)-4-methylphenol] butylated hydroxytoluene (BHT) as positive controls. Only compounds 3-[14'-nonadecenyl]phenol and 3-[16'-heptadecenyl]phenol exhibited activities [99]. Munodawafa [83] evaluated the antioxidant activities of methanol leaf extracts of $L$. edulis using the DPPH free radical scavenging assay with b-carotene as the positive control. The antioxidant activity of the extract was $93.9 \%$ inhibition which was comparable to $98.6 \%$ inhibition exhibited by the positive control [83].

\section{Cytotoxicity activities}

Sohni et al. [103] evaluated mutagenicity activities of aqueous leaf extracts of $L$. edulis using the Salmonella typhimurium mutagenicity assay using the strains TA97a, TA98, and TA100. The extract-induced frameshift mutations in S. typhimurium display marginal mutagenicity in the strain TA97a [103]. Sigidi et al. [89] evaluated the cytotoxicity activities of aqueous root extract of $L$. edulis on U937, MeWo, and Vero cell lines, using the 3-(4,5-dimethylthiazol-2-yl)-2,5-diphenyl tetrazolium bromide cell proliferation assay. The extract exhibited activities in all the three human tumor cancer cell lines [89].

\section{Toxicity activities}

Munodawafa [83] and Munodawafa et al. [104] evaluated toxicity of leaf extract of $L$. edulis using the brine shrimp lethality test with Nerium oleander $\mathrm{L}$. as a positive control. The extract exhibited median $\mathrm{LC}_{50}$ value of $971 \pm 86 \mu \mathrm{g} / \mathrm{mL}$ which was higher than $\mathrm{LC}_{50}$ value of $141.7 \mu \mathrm{g} / \mathrm{mL}$ exhibited by $N$. oleander, the positive control $[83,104]$. Banda [86] and Banda et al. [98] evaluated the toxicity activities of the aqueous leaf extracts of $L$. edulis aimed at establishing the median lethal dose $\left(\mathrm{LD}_{50}\right)$ of the extract in male albino rats at doses of $10 \mathrm{mg} / \mathrm{kg}, 100 \mathrm{mg} / \mathrm{kg}$, $300 \mathrm{mg} / \mathrm{kg}, 2000 \mathrm{mg} / \mathrm{kg}, 5000 \mathrm{mg} / \mathrm{kg}$, and $6000 \mathrm{mg} / \mathrm{kg}$. None of the doses caused death or caused rats to exhibit symptoms of toxicity. The $\mathrm{LD}_{50}$ value of the extract is, therefore, greater than $6000 \mathrm{mg} / \mathrm{kg}$ and falls within the nontoxic range $[86,98]$.

\section{CONCLUSION}

L. edulis is a well-known medicinal plant in tropical Africa. In many cases, the different plant parts such as bark, leaves, rootbark, and roots 
of L. edulis are used as herbal medicine for antiabortifacient, dilate birth canal, dizziness, sore eyes, sexually transmitted diseases, amenorrhea and dysmenorrhea, malaria, bilharzia, and gastrointestinal problems. Not much data are available on in vivo and toxicological properties of crude and compounds isolated from the species. Therefore, there is a need for further studies to focus on the toxicological and in vivo studies involving the crude extracts and chemical compounds isolated from the species.

\section{ACKNOWLEDGMENTS}

I would like to express my gratitude to the National Research Foundation, South Africa and Govan Mbeki Research and Development Centre, University of Fort Hare, for financial support to conduct this study.

\section{AUTHOR'S CONTRIBUTIONS}

The author declares that this work was done by the author named in this article.

\section{CONFLICTS OF INTEREST}

The author declares that they have no conflicts of interest.

\section{REFERENCES}

1. Glew RS, Vanderjagt DJ, Chuang LT, Huang YS, Millson M, Glew RH, et al. Nutrient content of four edible wild plants from West Africa. Plant Foods Hum Nutr 2005;60:187-93.

2. Lako J, Trenerry VC, Wahlqvist M, Wattanapenpaiboon N, Sotheeswaran S, Premier R. Phytochemical flavonols, carotenoids and the antioxidant properties of a wide selection of Fijian fruit, vegetables and other readily available foods. Food Chem 2007;101:1727-41.

3. Lamien-Meda A, Lamien CE, Compaoré MM, Meda RN, Kiendrebeogo M, Zeba B, et al. Polyphenol content and antioxidant activity of fourteen wild edible fruits from Burkina Faso. Molecules 2008;13:581-94.

4. Motlhanka DM, Makhabu SW. Medicinal and edible wild fruit plants of Botswana as emerging new crop opportunities. J Med Plant Res 2011;5:1836-42.

5. Leonti M. The co-evolutionary perspective of the food-medicine continuum and wild gathered and cultivated vegetables. Genet Res Crop Evol 2012;59:1295-302.

6. Tshikalange TE, Modishane DC, Tabit FT. Antimicrobial, antioxidant and cytotoxicity properties of selected wild edible fruits of traditional medicinal plants. J Herbs Spices Med Plant 2017;23:68-76.

7. Marco DB, Joseph V, John K. Mechanisms of disease: Antioxidants and atherosclerotic heart disease. N Engl J Med 1997;337:408-16.

8. Vinson JA, Su X, Zubik L, Bose P. Phenol antioxidant quantity and quality in foods: Fruits. J Agric Food Chem 2001;49:5315-21.

9. Wolfe K, Wu X, Liu RH. Antioxidant activity of apple peels. J Agric Food Chem 2003;51:609-14.

10. Aruoma OI. Free radicals, oxidative stress, and antioxidants in human health and disease. J Am Oil Chem Soc 1998;75:199-212.

11. Hu FB. Plant-based foods and prevention of cardiovascular disease: An overview. Am J Clin Nutr 2003;78:544S-551S

12. Riboli E, Norat T. Epidemiologic evidence of the protective effect of fruit and vegetables on cancer risk. Am J Clin Nutr 2003;78:559S-569S.

13. $\mathrm{Fu} \mathrm{L}, \mathrm{Xu} \mathrm{BT}, \mathrm{Xu} \mathrm{XR}$, Qin XS, Gan RY, Li HB, et al. Antioxidant capacities and total phenolic contents of 56 wild fruits from South China. Molecules 2010;15:8602-17.

14. Robards K, Prenzler PD, Tucker G, Swatsitang P, Glover W. Phenolic compounds and their roles in oxidative process in fruits. Food Chem 1999;66:401-36.

15. Cai Y, Luo Q, Sun M, Corke H. Antioxidant activity and phenolic compounds of 112 traditional Chinese medicinal plants associated with anticancer. Life Sci 2004;74:2157-84.

16. Li HB, Cheng KW, Wong CC, Fan KW, Chen F, Jiang Y. Evaluation of antioxidant capacity and total phenolic content of different fractions of selected microalgae. Food Chem 2007;102:771-6.

17. Li HB, Wong CC, Cheng KW, Chen F. Antioxidant properties in vitro and total phenolic contents in methanol extracts from medicinal plants. LWT Food Sci Technol 2008;41:385-90.

18. Stangeland T, Remberg SF, Lye KA. Total antioxidant activity in 35 Ugandan fruits and vegetables. Food Chem 2009;113:85-91.
19. Ling LT, Radhakrishnan AK, Subramaniam T, Cheng HM, Palanisamy UD. Assessment of antioxidant capacity and cytotoxicity of selected Malaysian plants. Molecules 2010;15:2139-51.

20. Tavares L, Carrilho D, Tyagi M, Barata D, Serra AT, Duarte CM, et al. Antioxidant capacity of Macaronesian traditional medicinal plants. Molecules 2010;15:2576-92.

21. Palmer E, Pitman N. Trees for Southern Africa covering all known indigenous species in Republic of South Africa, South West Africa, Botswana, Lesotho and Swaziland. Cape Town: AA Balkema; 1972.

22. Liengme CA. Plants used by the Tsonga people of Gazankulu. Bothalia 1981;13:501-18.

23. Campbell BM. The use of wild fruits in Zimbabwe. Econ Bot 1987; $41: 375-85$

24. Verzár R, Petri G. Medicinal plants in Mozambique and their popular use. J Ethnopharmacol 1987;19:67-80.

25. Food and Agriculture Organization (FAO). Traditional Food Plants. Rome: Food and Agriculture Organization; 1988.

26. McGregor J. Gathered produce in Zimbabwe's communal areas changing resource availability and use. Ecol Food Nutr 1995;33:163-93.

27. Schmidt E, Lotter M, McCleland W. Trees and Shrubs of Mpumalanga and Kruger National Park. Johannesburg: Jacana Media; 2002.

28. Van Wyk BE, Gericke N. People's Plants: A Guide to Useful Plants of Southern Africa. Pretoria: Briza Publications; 2007.

29. Maroyi A. The gathering and consumption of wild edible plants in Nhemacommunal area, Midlands Province, Zimbabwe. Ecol Food Nutr 2011;50:506-25.

30. Matongo K. Conservation and Use-Values of Medicinal Plants in Rural Eastern Zimbabwe: A Study of Selected Medicinal Plants. MSc Dissertation. Cape Town: University of the Western Cape; 2012.

31. Maroyi A, Cheikhyoussef A. Traditional knowledge of wild edible fruits in Southern Africa: Comparative use patterns in Namibia and Zimbabwe. Indian J Tradit Knowl 2017;16:385-92.

32. Hyde MA, Wursten BT, Ballings P, Palgrave CM. Lannea edulis (Sond.) Engl. var. edulis. Flora of Zimbabwe: Species Information; 2019. Available from: https://www.zimbabweflora.co.zw/speciesdata/ species.php?species id=136530. [Last accessed on 2019 Jun 12].

33. Magwede K, van Wyk BE, Van Wyk AE. An inventory of Vhavenda useful plants. S Afr J Bot 2019;122: 57-89

34. Mashile SP, Tshisikhawe MP, Masevhe NA. Indigenous fruit plants species of the Mapulana of Ehlanzeni district in Mpumalanga province, South Africa. S Afr J Bot 2019;122:180-3.

35. Van Wyk BE. The potential of South African plants in the development of new food and beverage products. S Afr J Bot 2011;77:857-68.

36. Van Wyk BE, Van Oudtshoorn B, Gericke N. Medicinal Plants of South Africa. Pretoria: Briza Publications; 2013.

37. Cunningham AB. African Medicinal Plants: Setting Priorities at the Interface between Conservation and Primary Health Care. Paris: People and Plants Working Paper 1, UNESCO; 1993.

38. Christenhusz MJ, Byng JW. The number of known plants species in the world and its annual increase. Phytotaxa 2016;261:201-17.

39. Fernandes RB, Fernandes A. Anacardiaceae. In: Exell AW, Fernandes A, Wild H, editors. Flora Zambesiaca: Mozambique, Malawi, Zambia, Rhodesia, Bechuanaland Protectorate. Vol. 2. London: Crown Agents for Overseas Governments and Administrations; 1966. p. 550-615.

40. Kokwaro JO. Anacardiaceae. In: Polhill RM, editor. Flora of Tropical East Africa. Rotterdam: AA Balkema; 1986. p. 1-59.

41. Germishuizen G, Meyer NL. Plants of Southern Africa: An Annotated Checklist. Pretoria: Strelitzia 14, National Botanical Institute; 2003.

42. Maroyi A. Lannea acida: A review of its medicinal uses, phytochemistry and pharmacological properties. Asian J Pharm Clin Res 2018;11:69-74.

43. Maroyi A. Lannea discolor: Its botany, ethnomedicinal uses, phytochemistry and pharmacological properties. Asian J Pharm Clin Res 2018;11:49-54.

44. Maroyi A. Lannea microcarpa: A review of its medicinal uses, phytochemistry and pharmacological properties. J Pharm Nutr Sci 2018;8:168-77.

45. Maroyi A. Lannea schimperi: Review of its botany, medicinal uses, phytochemistry and biological activities. Asian J Pharm Clin Res 2019;12:31-6.

46. Maroyi A. Review of ethnomedicinal, phytochemical and pharmacological properties of Lannea schweinfurthii (Engl.) Engl. Molecules 2019;24:e32.

47. Da Silva MC, Izidine S, Amude AB. A preliminary checklist of the vascular plants of Mozambique. Pretoria: Southern African Botanical Diversity Network Report No. 30; 2004.

48. Burrows JE, Willis CK. Plants of the Nyika Plateau. Pretoria: Southern African Botanical Diversity Network Report No. 31; 2005. 
49. Setshogo MP. Preliminary Checklist of the Plants of Botswana. Pretoria: Southern African Botanical Diversity Network Report, No. 37; 2005.

50. Figueiredo E, Smith GF. Plants of Angola. Pretoria: Strelitzia 22, National Botanical Institute; 2008.

51. Hedberg I, Friis I, Persson E. Flora of Ethiopia and Eritrea 1. Addis Ababa: Addis Ababa University; 2009

52. Gelfand M, Drummond RB, Mavi S, Ndemera B. The Traditional Medical Practitioner in Zimbabwe: His Principles of Practice and Pharmacopoeia. Gweru: Mambo Press; 1985.

53. Kritzinger Q. Antimicrobial Activity and Fumonisins Associated with Cowpea (Vigna unguiculata). PhD Thesis. Pretoria: University of Pretoria; 2005

54. Williamson J. Useful Plants of Malawi. Zomba: University of Malawi; 1975.

55. Morris B. Chewa Medical Botany: A Study of Herbalism in Southern Malawi. London: International African Institute; 1996.

56. Minja MM. Medicinal plants used in the promotion of animal health in Tanzania. Rev Sci Tech 1994;13:905-25.

57. Watt JM, Brandwijk MG. The Medicinal and Poisonous Plants of Southern and Eastern Africa. Edinburgh: E and S Livingstone; 1962.

58. Hutchings A. Zulu Medicinal Plants. Pietermaritzburg: University of Natal Press; 1996.

59. Deutschländer MS, Lall N, Van De Venter M. Plant species used in the treatment of diabetes by South African traditional healers: An inventory. Pharm Biol 2009;47:348-65.

60. Mabona U. Antimicrobial Activity of Southern African Medicinal Plants with Dermatological Relevance. MSc Dissertation. Johannesburg: University of the Witwatersrand; 2013.

61. Mabona U, Van Vuuren SF. Southern African medicinal plants used to treat skin diseases. S Afr J Bot 2013;87:175-93

62. Sigidi MT. Selection and Evaluation of ten Medicinal Plants used in the Vembe District for Life-Threatening Infections. PhD Thesis. Thohoyandou: University of Venda; 2017.

63. Steenkamp V. Traditional herbal remedies used by South African women for gynaecological complaints. J Ethnopharmacol 2003;86:97-108.

64. Gulumian M, Yahaya ES, Steenkamp V. African herbal remedies with antioxidant activity: A potential resource base for wound treatment. Evid Based Complement Altern Med 2018;2018:4089541.

65. Von Koenen E. Medicinal, Poisonous and Edible Plants in Namibia. Windhoek: Klaus Hess Publishers; 2001.

66. Pennacchio M, Jefferson L, Havens K. Uses and Abuses of PlantDerived Smoke: Its Ethnobotany as Hallucinogen, Perfume, Incense, and Medicine. Oxford: Oxford University Press; 2010.

67. Wild H, Gelfand M. Some native herbal remedies at present use in Mashonaland. Central Afr J Med 1959;5:292-305.

68. Ndamba J, Nyazema N, Makaza N, Anderson C, Kaondera KC. Traditional herbal remedies used for the treatment of urinary schistosomiasis in zimbabwe. J Ethnopharmacol 1994;42:125-32.

69. Nyazema NZ, Ndamba J, Anderson C, Makaza N, Kaondera KC. The doctrine of signatures or similitudes: A comparison of the efficacy of praziquantel and traditional herbal remedies used for the treatment of urinary schistosomiasis in Zimbabwe. Int J Pharmacogn 1994;32:142-8.

70. Ojewole OJ. Indigenous plants and schistosomiasis control in South Africa: molluscicidal activity of some Zulu medicinal plants. Boletín Latinoamer Caribe Plant Med Aromáticas 2004;3:8-22.

71. Chigora P, Masocha R, Mutenheri F. The role of indigenous medicinal knowledge (IMK) in the treatment of ailments in rural Zimbabwe: The case of Mutirikwi communal lands. J Sustain Dev Afr 2007·9·26-43.

72. Moraes J. Antischistosomal natural compounds: Present challenges for new drug screens. In: Rodriguez-Morales AJ, editor. Current Topics in Tropical Medicine. Rijeka: In Tech Open; 2012. p. 333-58.

73. Maroyi A. Traditional use of medicinal plants in south-central Zimbabwe: Review and perspectives. J Ethnobiol Ethnomed 2013;9:31.

74. Chingwaru W, Vidmar J, Kapewangolo PT. The potential of SubSaharan African plants in the management of human immunodeficiency virus infections: A Review. Phytother Res 2015;29:1452-87.

75. Maroyi A. Use of ethnomedicinal herbs to treat and manage schistosomiasis in Zimbabwe: Past trends and future directions. In: Martinez JL, Munoz-Acevedo A, Rai M, editors. Ethnobotany: Application of Medicinal Plants. London: CPC Press; 2019. p. 35-46.

76. Bally PR. Native medicinal and poisonous plants of East Africa. Bull Miscell Inf 1937;1:10-26.

77. Gelfand M. Medicine and Magic of the Mashonas. Cape Town: Juta; 1956.

78. Masinde PS. Medicinal plants of the Marachi people of Kenya. In: Van Der Maesen LJ, Van Der Burgt XM, De Rooy JM, editors. The Biodiversity of African Plants. Wageningen: Springer; 1996. p.747-53.
79. Amusan OO, Dlamini PS, Msonthi JD, Makhubu LP. Some herbal remedies from Manzini region of Swaziland. J Ethnopharmacol 2002;79:109-12.

80. Amusan OO, Sukati NA, Dlamini PS, Sibandze FG. Some Swazi phytomedicines and their constituents. Afr J Biotechnol 2007;6:267-72.

81. Amusan OO. Some ethnomedicines used for HIV/AIDS and related diseases in Swaziland. Afr J Plant Biotechnol 2009;3:20-6.

82. Maroyi A. Ethnobotanical study of medicinal plants used by people in Nhema communal area, Zimbabwe. J Ethnopharmacol 2011;136:347-54.

83. Munodawafa T. Screening of Some Traditional Medicinal Plants from Zimbabwe for Biological and Anti-Microbial Activity. MSc Dissertation. Harare: University of Zimbabwe; 2012.

84. Rupande G, Bukaliya R. The efficacy of indigenous knowledge in scaling up HIV/AIDS treatment-practices and challenges: The case of Zimbabwe. Int J Adv Res 2013;1:678-90.

85. Conde P, Figueira R, Saraiva S, Catarino L, Romeiras M, Duarte MC, et al. The botanic mission to Mozambique (1942-1948): Contributions to knowledge of the medicinal flora of Mozambique. Hist Cienc Saude Manguinhos 2014;21:539-85

86. Banda M. Assessing the Anti-Hyperglycemic and Antihyperlipidemic Effects of an Aqueous Extract of Lanne aedulis in Alloxan-Induced Diabetic Rats. MSc Dissertation. Lusaka: University of Zambia; 2018.

87. Lautenschläger T, Monizi M, Pedro M, Mandombe JL, Bránquima MF, Heinze C, et al. First large-scale ethnobotanical survey in the province of Uíge, Northern Angola. J Ethnobiol Ethnomed 2018;14:51.

88. Adebayo SA, Amoo SO. South African botanical resources: A gold mine of natural pro-inflammatory enzyme inhibitors? S Afr J Bot 2019;123:214-27.

89. Sigidi MT, Traoré AN, Boukandou MM, Tshisikhawe MP, Ntuli SS, Potgieter N. Anti-HIV, pro-inflammatory and cytotoxicity properties of selected Venda plants. Indian J Tradit Knowl 2017;16:545-52.

90. Salehi B, Kumar NV, Şener B, Sharifi-Rad M, Kılıç M, Mahady GB, et al. Medicinal plants used in the treatment of human immunodeficiency virus. Int J Mol Sci 2018;19:e1459.

91. Gessler MC, Nkunya MH, Mwasumbi LB, Heinrich M, Tanner M. Screening Tanzanian medicinal plants for antimalarial activity. Acta Trop 1994;56:65-77.

92. Fowler DG. Traditional Fever Remedies: A List of Zambian Plants. London, Kew: Kew Publishing, Royal Botanic Gardens; 2006.

93. Shangali CF, Zilihon IJ, Mwang'ingo PL, Nummelin M. Use of medicinal plants in the eastern arc mountains with special reference to the Hehe ethnic group in the Udzungwamountains, Tanzania. J East Afr Nat Hist 2008;97:225-54.

94. Ssegawa P, Kasenene JM. Medicinal plant diversity and uses in the Sango bay area, Southern Uganda. J Ethnopharmacol 2007;113:521-40.

95. Chinemana F, Drummond RB, Mavi S, De Zoysa I. Indigenous plant remedies in Zimbabwe. J Ethnopharmacol 1985;14:159-72.

96. Kambizi L, Afolayan AJ. An ethnobotanical study of plants used for the treatment of sexually transmitted diseases (njovhera) in Guruve district, Zimbabwe. J Ethnopharmacol 2001;77:5-9.

97. Chinsembu KC, Hijarunguru A, Mbangu A. Ethnomedicinal plants used by traditional healers in the management of HIV/AIDS opportunistic diseases in Rundu, Kavango East region, Namibia. S Afr J Bot 2015;100:33-42.

98. Banda M, Nyirenda J, Muzandu K, Sijumbila G, Mudenda S Antihyperglycemic and antihyperlipidemic effects of aqueous extracts of Lanne aedulis in alloxan-induced diabetic rats. Front Pharmacol 2018;9:1099.

99. Queiroz EF, Kuhl C, Terreaux C, Mavi S, Hostettmann K. New dihydroalkylhexenones from Lannea edulis. J Nat Prod 2003;66:578-80.

100. Mølgaard P, Nielsen SB, Rasmussen DE, Drummond RB, Makaza N, Andreassen $\mathrm{J}$, et al. Anthelmintic screening of Zimbabwean plants traditionally used against schistosomiasis. J Ethnopharmacol 2001;74:257-64

101. Munodawafa T, Chagonda LS, Moyo SR. Antimicrobial and phytochemical screening of some Zimbabwean medicinal plants. J Biol Active Prod Nat 2013;3:323-30.

102. Chivengwa C, Mandimutsira T, Gere J, Magogo C, Chikanza I, Vidmar J, et al. Inhibition of Escherichia coli and Salmonella spp. by traditional phytomedicines that are commonly used to treat gastroenteritis in Zimbabwe. Int J Pharmacol Pharm Sci 2016;10:50.

103. Sohni YR, Davis CL, DesChamps AB, Kale PG. Frameshift mutations in salmonella induced by the extracts of medicinal herbs Lannea edulis (Sond.) Engl. and Monotes glaber Sprague. Environ Mol Mutagen 1995;25:77-82

104. Munodawafa T, Moyo S, Chipurura B, Chagonda L. Brine shrimp lethality bioassay of some selected Zimbabwean traditional medicinal plants. Int J Phytopharmacol 2016;7:229-32. 